\title{
Plant community and tissue chemistry responses to fertilizer and litter nutrient manipulations in a temperate grassland
}

Jean J. Pan · Brittany Widner •

Deborah Ammerman · Rebecca E. Drenovsky

Published online: 14 July 2009

(C) Springer Science+Business Media B.V. 2009

\section{Erratum to: Plant Ecol}

DOI 10.1007/s11258-009-9630-3

Page 3, line 238 under Materials and methods paragraph should be read as "18-6-12 NPK" and NOT “18-16-12”.

The online version of the original article can be found under doi:10.1007/s11258-009-9630-3.

J. J. Pan $(\bowtie) \cdot$ B. Widner · D. Ammerman Department of Biology, The University of Akron, 302 Buchtel Common, Akron, OH 44325-3908, USA

e-mail: jepan@uakron.edu

R. E. Drenovsky

Biology Department, John Carroll University, University Heights, OH 44118, USA 